\title{
外乱オブザーバを用いた空気式パラレル マニピュレータのインピーダンス制御
}

\author{
則 次 俊 郎* 高 岩 昌 弘*
}

\section{Impedance Control of Pneumatic Parallel Manipulator Using Disturbance Observer}

Toshiro Noritsugu* and Masahiro Takaiwa*

\begin{abstract}
In order to make a robot perform a contact task with an environment, robot must have an enough skillfulness and compliance simultaneously. Parallel manipulator has attracted an interest because of its features such as a multiple d.o.f. for its compact mechanism which is available for complicated tasks. In the meanwhile pneumatic actuator has a high power/weight ratio and an inherent compliance function due to the air compressibility which makes it possible to perform a minute force regulation. In this paper we apply an impedance control to the prototype of parallel manipulator driven by pneumatic cylinders and its control performances are investigated.

There are 2 general impedance control strategies, one is force based type and the other is position based one. In the former one the influence of manipulator's dynamics such as inertia force and damping one affect on the control variable directly, while in the latter one applied external force works as a disturbance. Therefore we construct both types of control system based on the pressure control system to kill out the influence of these disturbances which are estimated with a dimension of a pressure by using a disturbance observer. Moreover we comprise an simplified position based impedance control system. The control performances are compared among the proposed three control systems analytically and the validity of them are proved by some experiments.
\end{abstract}

Key Words: Parallel Manipulator, Pneumatic Servo System, Impedance Control, Pressure Control, Disturbance Observer

\section{1. 緒言}

環境との接触を伴う作業を行うロボットの手先には, 複雑な 運動にも対応できる自由度と, 接触力の微細な制御や衝突反力 の吸収に必要とされる柔軟性が要求される.

近年, 産業界において注目されているパラレルマニピュレー 夕は,コンパクトな構造ながら多自由度を有し, 可動部の慣性 も小さいため, 手先の微細な運動が要求される作業に適してい る. 一方, 空気圧シリンダは, 高い出力/重量比を有すると同 時に，それ自身空気の圧縮性に起因する低剛性特性を持つため, パラレルマニピュレータのアクチュエータとして使用すれば, 本質的にコンプライアントな小型マニピュレータが実現できる. このようなマニピュレータは, 近い将来必要となるであろう人 間を相手にするような作業において特に重要となる.

このような作業を効率よく運用するには，位置や力のみでな く，位置と力の動的な関係である機械インピーダンスを積極的 に制御する必要が生じる [1]. パラレルマニピュレータのパッシ ブなインピーダンス特性については前田ら [2]により解析され，

原稿受付 1997 年 10 月 14 日

* 岡山大学工学部システム工学科

${ }^{*}$ Faculty of Engineering, Okayama University
挿入作業に与える効果等が報告されている．しかし，パラレル マニピュレータのインピーダンス特性をアクティブに制御した 例はほとんど見当たらない.

本研究では空気圧シリンダをアクチュエータとするパラレル マニピュレータにインピーダンス制御系を構成する。まず，従 来どおりカベース型，および位置ベース型インピーダンス制御 系を構成する．前者ではマニピュレータの運動に伴い，その慣 性力や粘性力等が制御量であるマニピュレー夕発生力に直接影 響を及ほすす。た，後者の場合は印加された外力が内部の位置 制御系に外乱として作用する。よって，制御性能向上にはこれ らの影響を効果的に低減する制御法の開発が必要である。そこ で, 従来より提案されている外乱オブザーバ [3] の考えを利用 して，圧力制御を主体とする制御法 [4] を適用する。また，位置 ベース型を改良した，制御アルゴリズムが単純な簡易位置ベー ス型制御法について，その有効性を検討する。

これらの制御手法について，設定インピーダンスの実現性能 を理論的に解析し, 解析の妥当性を実験により検証することで, 提案する手法の有効性と接触作業における本マニピュレータの 実用の可能性を示す. 


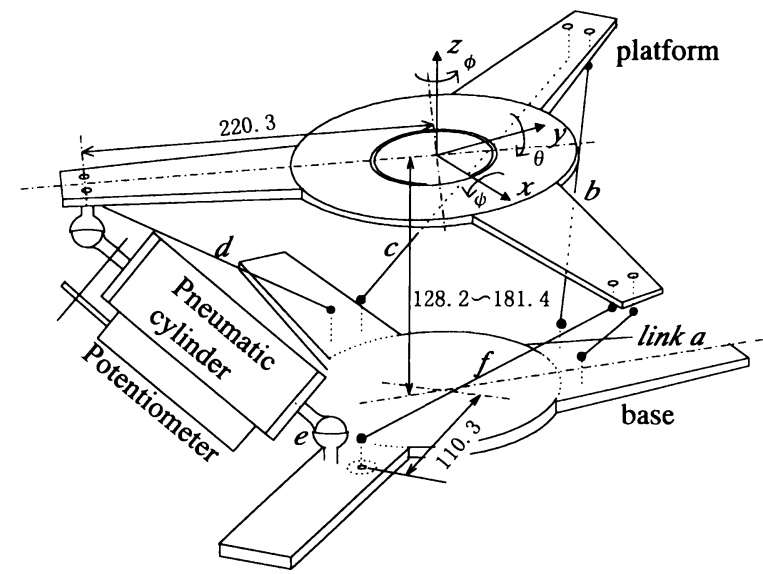

Fig. 1 Schematic diagram of parallel manipurator

Table 1 Work space of manipulator

\begin{tabular}{|c|c|c|}
\hline $\mathrm{x}$ & $\mathrm{y}$ & $\mathrm{z}$ \\
\hline$-26.2 \sim 26.3[\mathrm{~mm}]$ & $-22.9 \sim 22.9$ & $-26.6 \sim 26.6$ \\
\hline
\end{tabular}

(a) horizontal direction

\begin{tabular}{|c|c|c|}
\hline$\phi$ & $\theta$ & $\psi$ \\
\hline$-0.215 \sim 0.215[\mathrm{rad}]$ & $-0.128 \sim 0.113$ & $-0.130 \sim 0.130$ \\
\hline
\end{tabular}

(b) rotational direction

\section{2. 空気式パラレルマニピュレータ}

\section{1 マニピュレータの概要}

Fig. 1 に試作した空気式パラレルマニピュレータの概観を 示す. 各リンクにはベロフラムシリンダ（内径 $31.5[\mathrm{~mm}]$, ス トローク $35[\mathrm{~mm}])$ を使用する. 各シリンダのピストンロッド がストローク中央のときのプラットフォーム中心点をベース 座標系の原点とし，その姿勢を基準姿勢とする。手先位置 $x$, $y, z$ は原点からの変位であり, 姿勢 $\phi, \theta, \psi$ はロール, ピッ チ，ヨー角を用いて表される。これらをまとめて手先べクト ル $h=[x, y, z, \phi, \theta, \psi]^{\mathrm{T}}$ とする. また，ピストン変位ベクトル $\ell=\left[\ell_{a}, \ell_{b}, \ldots, \ell_{f}\right]^{\mathrm{T}}$ とおく. パラレルマニピュレータでは, 手 先ベクトルからピストン変位への写像である逆運動学が次式の ように解析的に求まる.

$$
\ell=I_{n v}(h)=\left[I_{n v a}(h), I_{n v b}(h), \ldots, I_{n v f}(h)\right]^{T}
$$

また,プラットフォーム中心に取り付けられた 6 軸力/ト ルクセンサにより検出される力/トルクベクトルを $f_{p}=$ $\left[f_{x}, f_{y}, f_{z}, \tau_{\phi}, \tau_{\theta}, \tau_{\psi}\right]^{\mathrm{T}}$ とし, リンクに作用するカベクトルを $f_{\ell}=\left[f_{a}, f_{b}, \ldots, f_{f}\right]^{\mathrm{T}}$ とする.

新井の方法 [5]により, 基準姿勢において原点での発生力/卜 ルクの一様性を考慮して設計した結果, 上部プラットフォーム の径は下部ベース部の径の 2 倍となり, 特徵的な形状を有する. 可動範囲を Table 1 に示す.

Fig. 2 に空気圧駆動回路を示す。ロッド側シリンダ室は一定 圧力供給源 $\left(p_{2}=236[\mathrm{kPa}]\right)$ に接続され, ヘッド側シリンダ室 内圧力 $p_{1}$ はパルス幅変調制御方式（搬送周波数 $50[\mathrm{~Hz}]$ ）で駆

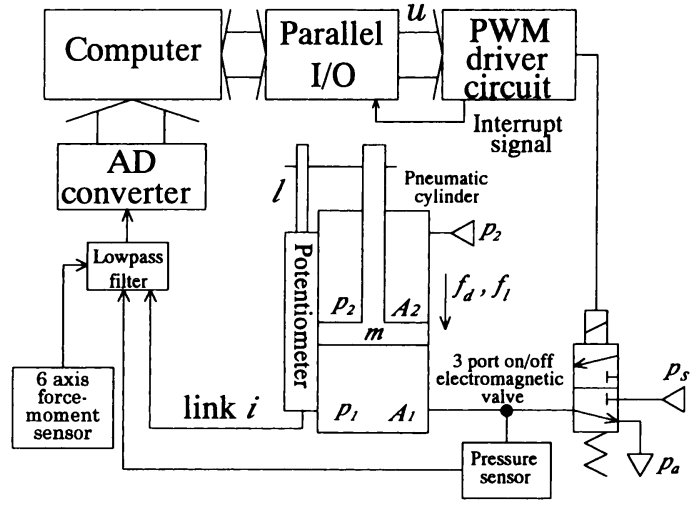

Fig. 2 Pneumatic driving circuit

動される 3 ポートオンオフ電磁弁により調整される．供給圧 力 $p_{s}$ は $490[\mathrm{kPa}]$ とする. ピストンロッドの変位はシリンダに 取り付けたポテンショメータ（分解能 $12.2[\mu \mathrm{m}]$ ) で測定され, ヘッド側シリンダ室内圧力は圧力センサ（分解能 $0.15[\mathrm{kPa}]$ ) で検出される.コンピュータで計算されたデューティー比に相 当する制御信号 $u$ は 12 ビットの分解能で弁駆動回路に入力さ れる. 制御信号は搬送周波数に同期させ, サンプリングタイム は $20[\mathrm{~ms}]$ とする.

\section{2 空気圧駆動部のモデル化}

マニピュレータが基準姿勢となるピストン位置近傍において， 空気圧駆動部の線形化モデルを導出する.

制御信号 $u$ と制御弁開口面積は比例すると仮定すると, ピス トンの運動方程式およびシリンダ室内の状態方程式は次式で与 えられる。

$$
\begin{aligned}
p_{1} A_{1}-p_{2} A_{2} & =m \frac{d^{2} \ell}{d t^{2}}+b \frac{d \ell}{d t}+f_{d}+f_{\ell} \\
T_{p} \frac{d p_{1}}{d t} & =-p_{1}+K_{p} u-K_{v} \frac{d \ell}{d t}
\end{aligned}
$$

ここで, $A_{1}, A_{2}$ : ヘッド側およびロッド側シリンダ室有効断面 積, $p_{1}, p_{2}$ :ヘッド側およびロッド側シリンダ室内圧力, $m$ : 等価慣性質量, $b$ : 粘性摩擦係数, $f_{d}$ : 重力, クーロン摩擦力お よびリンク間干渉力の合計, $f_{\ell}$ : 手先に作用する外力が等価的 にリンクに及ほす力, $\ell$ : ピストン変位, $K_{p}, K_{v}$ : それぞれ, 圧力に及ほす制御信号およびピストン速度の影響を表す係数, $T_{p}$ : 圧力 $p_{1}$ の $u$ に対する応答の時定数である.

\section{3.インピーダンス制御系の構成}

ラプラス変換後の変数を大文字で表すとすると, インピーダ ンス制御とは, 式（4）に示すように, マニピュレータに作用 した外力/モーメント $F_{p}$ と, これにより生じた位置/姿勢の目 標值からの偏差 $H_{r}-H$ の比が設定した機械インピーダンス $I_{m p}$ となるように位置/姿勢, もしくはカ/トルクを制御するこ とである. 前者は位置ベース型, 後者は力ベース型と呼ばれ, それぞれ, 内部に位置制御系, および力制御系を構成すること で，式 (4) の関係を実現する.

$$
F_{p}=I_{m p}\left(H_{r}-H\right)=\left(M s^{2}+B s+K\right)\left(H_{r}-H\right)
$$




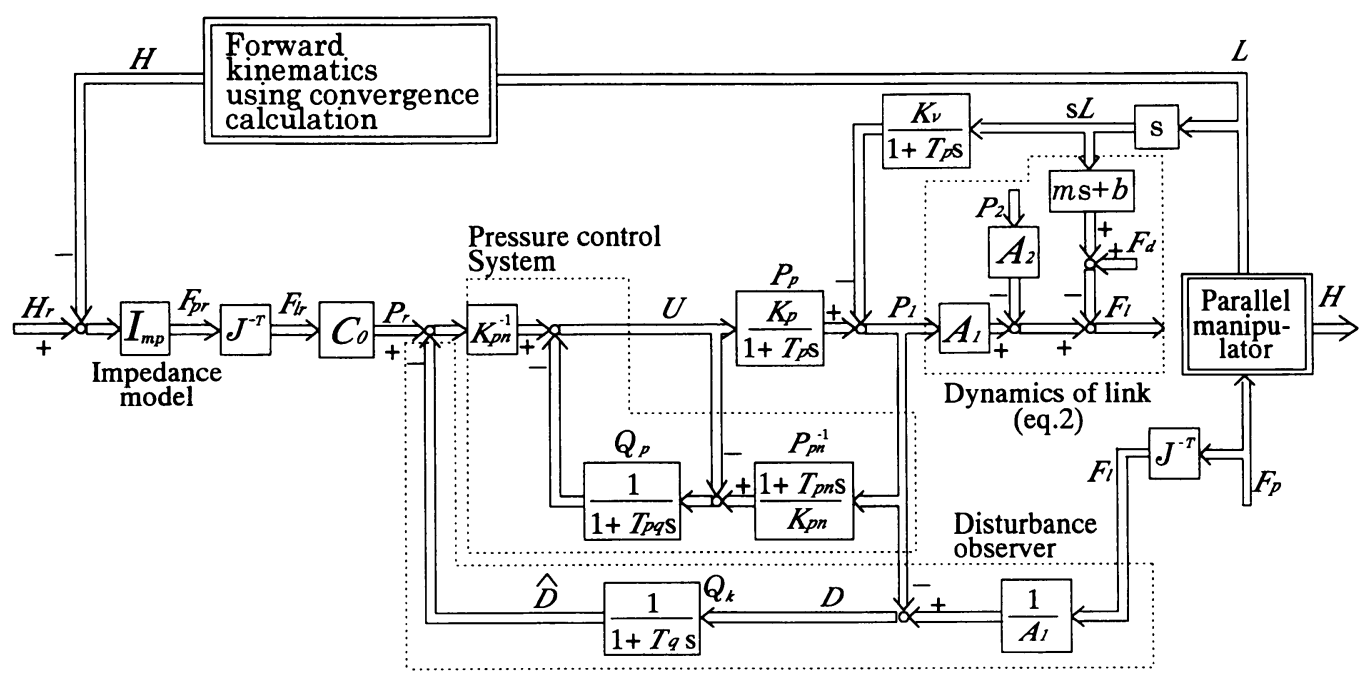

Fig. 3 Force based impedance control system

ここで, $M, B, K$ はそれぞれ, 設計者が設定する, 慣性, 粘

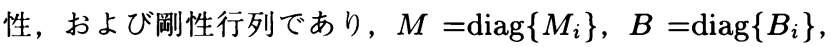
$K=\operatorname{diag}\left\{K_{i}\right\}, i=x, y, \ldots, \psi$ である. 以後に示すブロック 線図において, 各変数はラプラス変換された状態変数べクトル であり，各ブロックは内部の要素を対角成分とする伝達関数行 列を示す. 簡単のためラプラス変換を表す (s) は省略する.

\section{1 カベース型インピーダンス制御系の構成}

Fig. 3 に力ベース型インピーダンス制御系を示す. 手先の位 置・姿勢の偏差 $H_{r}-H$ に設定インピーダンスモデル $I_{m p}$ を かけ, 手先の目標力/トルク $F_{p r}$ を生成する. 一般にパラレル マニピュレータでは $H$ は解析的に求められないため, 本研究 では収束計算を用いてオンラインで算出している。続いて次式 に示す仮想仕事の原理より，リンクあたりの目標力 $F_{\ell r}$ に変換 し，各リンク独立に力制御系を構成する.

$$
f_{p}=J^{T} f_{\ell}
$$

ここで，Jはヤコビ行列であり，次式に示すように，式 (1) の 両辺を時間微分することにより得られる.

$$
\frac{d l}{d t}=\frac{\partial I_{n v}(h)}{\partial h} \frac{d h}{d t}=J(h) \frac{d h}{d t}
$$

通常, 力制御系を構成する場合, マニピュレータに作用する 力/トルクの目標値からの偏差 $F_{p r}-F_{p}$ から各リンクの力偏 差 $F_{\ell r}-F_{\ell}$ に変換し, 適当な制御器 (PI 制御器等) を用いて 制御入力を算出するのが一般的と思われるが, 重力, 摩擦力の ほかに, 慣性力, 粘性力等のマニピュレータの運動に起因する 力が直接制御量 $F_{\ell}$ に現れるため，これら外乱を積極的に低減 することを考える.

本研究では，従来より提案している圧力制御を主体とする手 法を用いる。 まず, 圧力 $P_{1}$ から $F_{\ell}$ までの伝達部（この場合, ヘッド側シリンダ室有効断面積 $\left.A_{1}\right)$ に対して, 外乱オブザー バ [3] を応用する. 式 (2)より, 推定外乱 $D\left(=F_{\ell} / A_{1}-P_{1}\right)$ は次式のように表される。

$$
D=-\frac{P_{2} A_{2}}{A_{1}}-\frac{(m s+b) s L}{A_{1}}-\frac{F_{d}}{A_{1}}
$$

次に, $D$ を補償する圧力を生成する. 圧力応答においてはピ ストン速度の影響が外乱として作用し, また, 制御信号 $U$ か ら圧力 $P_{1}$ までの伝達部には, 通常, 無視できない非線形性が 存在する.よって, 圧力制御系にも外乱オブザーバを導入し, 外乱として作用するピストン速度の影響の低減と, 圧力伝達部 に存在する非線形性の補償を行う。

両外乱オブザーバが理想的に機能した場合， $P_{r}$ から $F_{\ell}$ ま での伝達関数は $K_{p n}^{-1} P_{p n} A_{1}$ となる. コントローラ $C_{0}$ はこの ダイナミクスをキャンセルするために挿入されており，その結 果, $F_{\ell}=F_{\ell} r$ となり, 式 $(4)$ の関係が実現される.

\section{2 位置ベース型インピーダンス制御系の構成}

Fig. 4 に位置ベース型インピーダンス制御系を示す. 手先に 作用する力/トルク $F_{p}$ に設定インピーダンスの逆モデルをか けてフィードバックし, 内部に位置制御系を構成する [6]. (a) は内部の位置制御系を関節サーボに基づいて設計した場合，(b) は手先座標に基づいて構成した場合である。(a), (b) 共に, 先 述した圧力制御系に基づいて設計されており，圧力制御系への 補償入力として, 圧力 $P_{1}$ からピストン速度 $s L$ までの伝達部 に応用した外乱オブザーバによる推定外乱がフィードバックさ れる. 両外乱オブザーバが理想的に機能した場合, $P_{r}$ から $s L$ までの伝達特性は

$$
s L=K_{p n}^{-1} P_{p n} P_{k n} P_{r}=\frac{1}{1+T_{p n} s} \frac{A_{1}}{m_{n} s+b_{n}} P_{r}
$$

となり, 両外乱オブザーバのノミナルモデルの積で近似される. 今, ノミナルモデル $P_{p n}, P_{k n}$ のうち, どちらか一方の時定数 は無視できるほど小さく設定できると仮定する.

(a)の場合, ピストン変位が満たすべき閉ループ特性を次式 の二次系とおく.

$$
\frac{L}{L_{d}}=G_{m}=\frac{\omega_{n}^{2}}{s^{2}+2 \zeta \omega_{n} s+\omega_{n}^{2}}
$$

変形して,

$$
s L=\frac{\omega_{n}^{2}}{s+2 \zeta \omega_{n}}\left(L_{d}-L\right)
$$




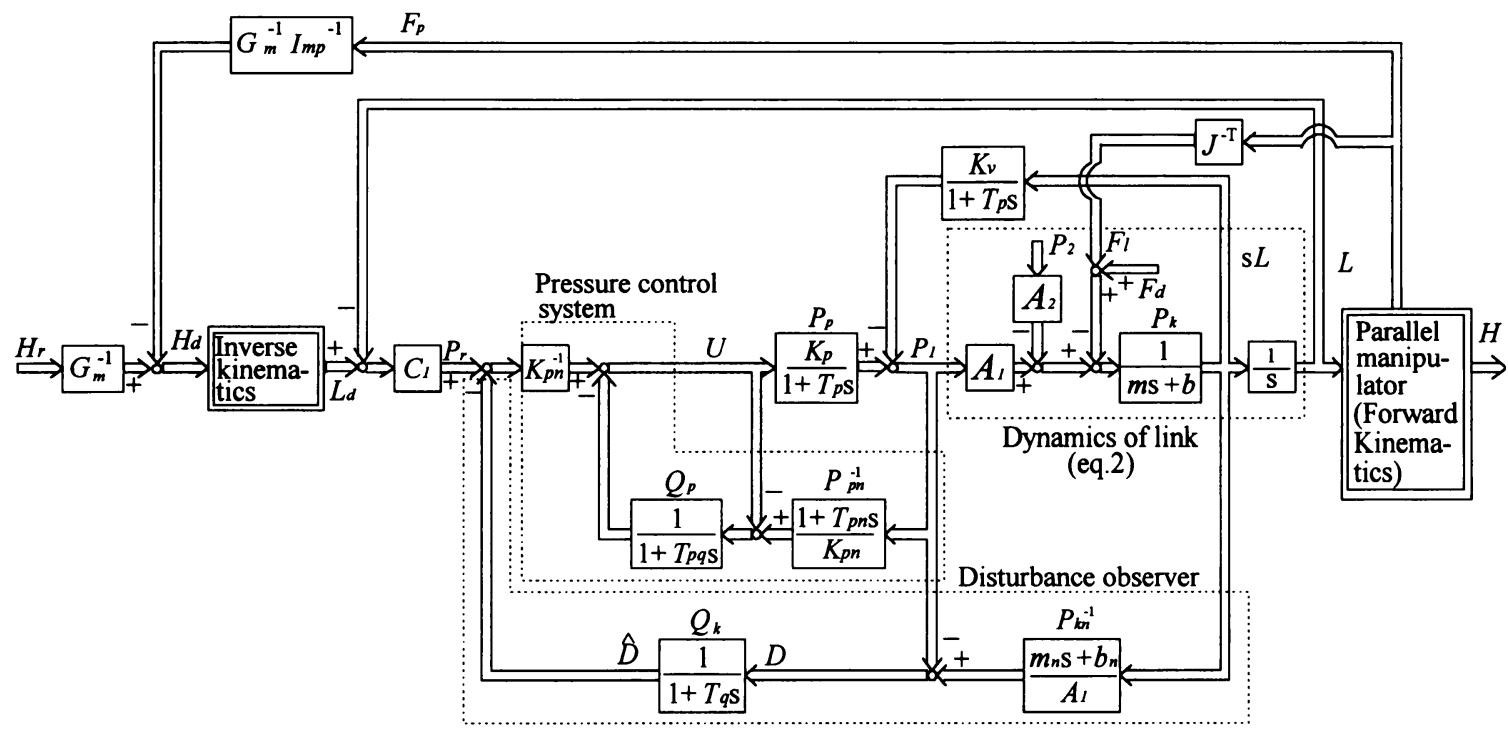

(a) Joint servo type

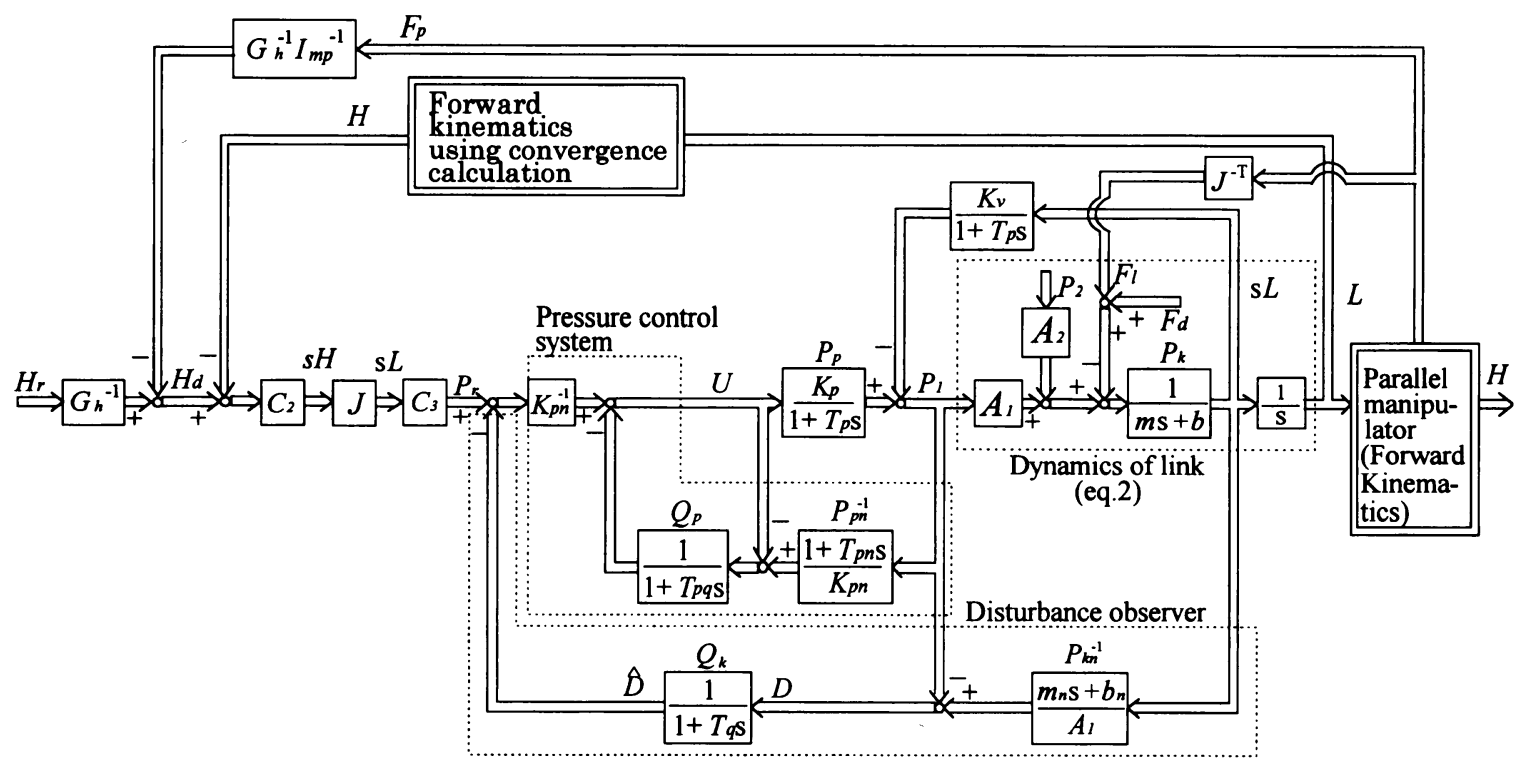

(b) Hand coordinate type

Fig. 4 Position based impedance control system

式 $(8)$ に代入して $s L$ を消去すると, 目標圧力 $P_{r}$ は $P_{k n}, P_{p n}$ のうち無視できない方のダイナミクスを考慮して, 仮想位置偏 差 $L_{d}-L$ より次式に示すコントローラ $C_{1}$ を介して得られる.

$$
\begin{aligned}
T_{p n} \ll m_{n} / b_{n}: & \\
C_{1}= & \frac{\omega_{n}^{2}\left(m_{n} s+b_{n}\right)}{\left(s+2 \zeta \omega_{n}\right) A_{1}} \\
m_{n} / b_{n} \ll T_{p n}: & \\
C_{1}= & \frac{\omega_{n}^{2}\left(1+T_{p n} s\right) b_{n}}{\left(s+2 \zeta \omega_{n}\right) A_{1}}
\end{aligned}
$$

ら $H$ までの特性も $G_{m}$ で与えられる。よって，位置制御部の ダイナミクスを補償するために, $G_{m}^{-1}$ を $H_{r}$ と $F_{p}$ にかけて いる．この場合， $H_{r}$ を微分することになるが， $H_{r}$ の未来値 を使用できるとする。この結果，環境に拘束されない自由空間 $\left(F_{p}=0\right)$ においては，追従遅れなしの軌道制御 $\left(H_{r}=H\right)$ か 達成され，拘束空間においては式（4）に示す設定インピーダ ンスが実現される。

Fig. 4 (b) の場合も基本的な設計概念は同じである。この場 合は，次式に示寸閉ループ特性を手先のベクトル空間において 実現することを考える。

$$
\frac{H}{H_{d}}=G_{h}=\frac{\omega_{n}^{2}}{s^{2}+2 \zeta \omega_{n} s+\omega_{n}^{2}}
$$


変形して,

$$
s H=\frac{\omega_{n}^{2}}{s+2 \zeta \omega_{n}}\left(H_{d}-H\right)=C_{2}\left(H_{d}-H\right)
$$

となり，式（12）を満足する望ましい手先速度は手先位置偏差 $H_{d}-H$ からコントローラ $C_{2}$ を介して得られる. さらに, 望 ましい手先速度は式 $(6)$ よりヤコビアン $J(h)$ を介して望ま しいリンク速度に変換される. よって, Fig. 4 (a) に示す制御法 と同様にして, 望ましいリンク速度を実現するための目標圧力 $P_{r}$ を両ノミナルモデル $P_{k n}, P_{p n}$ の時定数の大小により, 次式 のコントローラ $C_{3}$ を介して算出する.

$$
\begin{aligned}
T_{p n} \ll m_{n} / b_{n}: & \\
C_{3}= & \frac{m_{n} s+b_{n}}{A_{1}} \\
m_{n} / b_{n} \ll T_{p n}: & \\
C_{3}= & \frac{\left(1+T_{p n} s\right) b_{n}}{A_{1}}
\end{aligned}
$$

$P_{r}$ 以降の制御部は Fig. $4($ a) と同じである.

本マニピュレータでは構造上逆運動学特性がほほ線形とみな せ，その結果, Fig. 4 に示す制御系の位置制御部は (a), (b) と もほほ等しい制御性能を有することが確認されている[6].

\section{3 簡易位置ベース型インピーダンス制御系の構成}

制御アルゴリズムはより簡易なものに越したことはない. 本 研究では新たに簡易位置ベース型インピーダンス制御系を提案 する.ブロック線図を Fig. 5 に示す.これは, 以下のようにし て構成される. 式 (4) を次式のように変形すれば, マニピュ レータの目標速度 $s H$ が導かれる。

$$
\left\{\left(H_{r} \frac{M s^{2}+B s+K}{K}-H\right) K-F_{p}\right\} \frac{1}{M s+B}=s H
$$

よって, $s H$ 以降を Fig. $4(\mathrm{~b})$ に示す制御系と同様に構成する ことで, Fig. 4 に示す制御系と同様に, 理想的には自由空間に おける目標軌道追従性 $\left(H_{r}=H\right)$ と, 拘束空間におけるイン ピーダンス制御性能が保証される. 本制御系は, Fig. 4 (b) に示 す制御系において，位置制御部の設定モデル $G_{h}$ を

$$
G_{h}^{-1}=\frac{M s^{2}+B s+K}{K}
$$

となるように設定した場合と同値である. Fig. 4 (b) と比較し て, $F_{p}$ は直接フィードバックされるため, 制御アルゴリズム の計算時間が短縮される。本制御系は位置制御部の特性を設定 インピーダンスモデルで代用することで簡易化をはかるもので あるが, インピーダンスパラメータを設定すると外乱として作 用する外力から制御量までの特性も一意に決定されるため, 設 計の自由度は低下する。

\section{4 設定インピーダンスの実現精度}

\section{4 .1 カベース型の場合}

Fig. 3 に示す制御系において，設定インピーダンスの実現精 度を検討する. $C_{0}$ により $P_{r}$ から $F_{\ell}$ までの伝達関数が補償さ
れていると仮定すると，各リンクにおける入出力特性は,

$$
\begin{aligned}
F_{\ell} & =F_{\ell r}-\beta_{f} s L=F_{\ell r}-\beta_{f} J s H \\
\beta_{f} & =\left(1-Q_{k} G_{p}\right)(m s+b)
\end{aligned}
$$

となる.簡単のため, 圧力制御系の閉ループ伝達関数を $G_{p}$ で 示し,また， $F_{d}=0$ としている. Fig. 3 より，

$$
F_{\ell r}=J^{-T} I_{m p}\left(H_{r}-H\right)
$$

であるから, 式（17）へ代入して式（5）を考慮すると, 次式 を得る。

$$
F_{p}=I_{m p}\left\{H_{r}-H\left(I+I_{m p}^{-1} J^{T} J \beta_{f} s\right)\right\}
$$

ここで，実現精度の指標として $I D_{f}$ を導入する。

$$
\begin{aligned}
I D_{f} & =I+I_{m p}^{-1} J^{T} J \beta_{f} s \\
& =I+I_{m p}^{-1} J^{T} J\left(1-Q_{k} G_{p}\right)(m s+b) s
\end{aligned}
$$

$I D_{f}$ の周波数特性ができるだけ高周波数域まで 1 となるほど, 設定インピーダンスは高周波数域まで実現される.また, 式 （19）より, 外力に拘束されない空間 $\left(F_{p}=0\right)$ では, 位置制御系 の閉ループ伝達関数は $I D_{f}^{-1}$ で与えられる. 位置制御性能の観 点からも $I D_{f}=1$ が望ましい. 式 $(20)$ より, 高インピーダ ンスに設定するほど $I D_{f}=1$ となり安く実現精度の向上が期 待できるが, Fig. 3 よりループゲインが増大し, 安定性の低下 が予想される。

\section{4 .2 位置ベース型の場合}

Fig. 4 (a) に示す制御系における設定インピーダンスの実現 精度を調べる. 各リンクの入出力特性は

$$
\begin{aligned}
L & =\alpha L_{d}-\beta_{p} F_{\ell} \\
\beta_{p} & =\frac{s+2 \zeta \omega_{n}}{b_{n}\left(s^{2}+2 \zeta \omega_{n} s+\omega_{n}^{2}\right)}\left(1-Q_{k} G_{p}\right)
\end{aligned}
$$

と表される.ここで, $\alpha$ は閉ループ伝達関数であり, 理想的に は式 (9) で与えられる. 式 (5) と逆運動学 $I_{n v}$ の線形性を仮 定すると, 式 (21) は

$$
I_{n v}(H)=\alpha I_{n v}\left(H_{d}\right)-\beta_{p} J^{-T} F_{p}=I_{n v}\left(\alpha H_{d}\right)-\beta_{p} J^{-T} F_{p}
$$

と表される.一方, Fig. 4 より，

$$
H_{r}-I_{m p}^{-1} F_{p}=G_{m} H_{d}
$$

今, $\alpha=G_{m}$ が成立しているとし, 式（22）に代入し， $G_{m} H_{d}$ を消去すると，

$$
I_{n v}\left(H_{r}-I_{m p}^{-1} F_{p}\right)-I_{n v}(H)=\beta_{p} J^{-T} F_{p}
$$

$I_{n v}$ の線形性と式（6）より，式（24）の左辺は,

$$
\begin{aligned}
& I_{n v}\left(H_{r}-I_{m p}^{-1} F_{p}\right)-I_{n v}(H)=J\left(H_{r}-I_{m p}^{-1} F_{p}-H\right) \\
& \text { よって, 式 }(24) \text { は } \\
& \quad J\left[H_{r}-H-I_{m p}^{-1}\left\{I+\left(J^{T} J\right)^{-1} I_{m p} \beta_{p}\right\} F_{p}\right]=0
\end{aligned}
$$




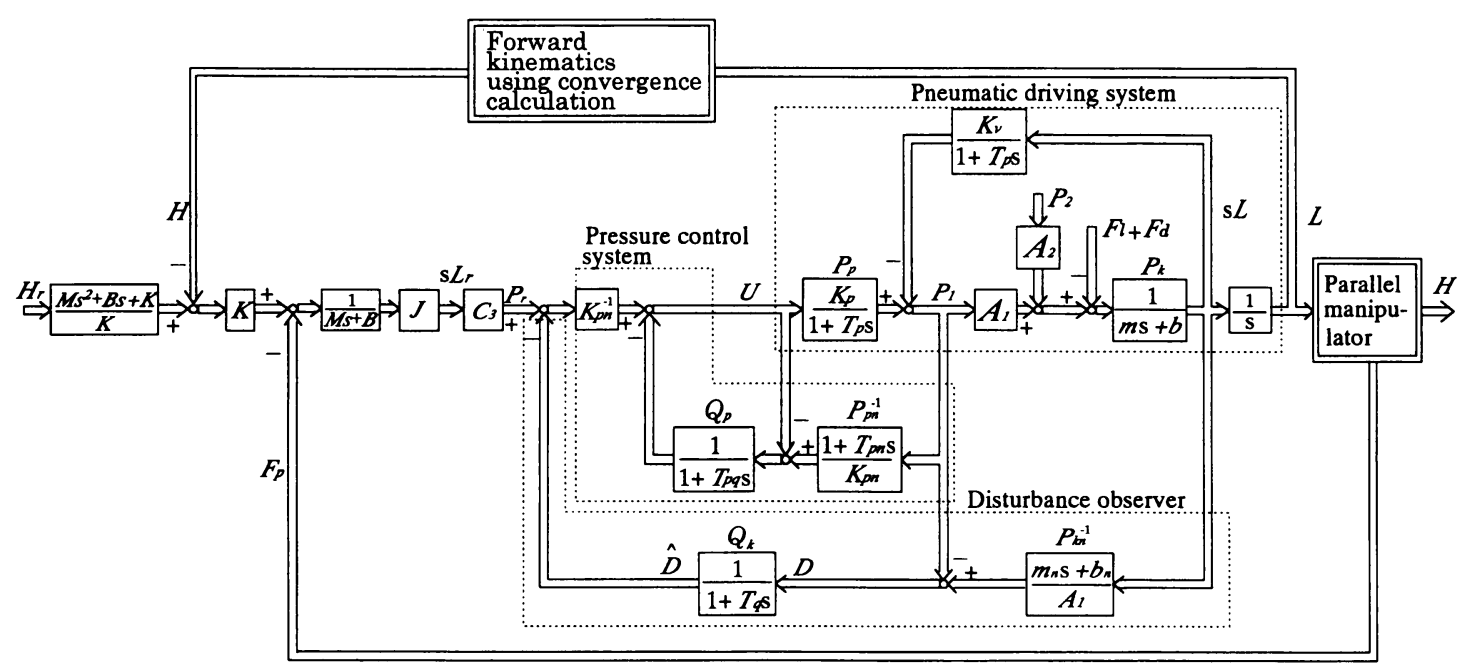

Fig. 5 Simplified position based impedance control system

と表される. Fig. 4 (b) に示す制御系においても同様にして, 式 （26）が導出される.よって, 設定インピーダンスの実現精度 の指標 $I D_{p}$ を次式で与える.

$$
\begin{aligned}
I D_{p}^{-1} & =I+\left(J^{T} J\right)^{-1} I_{m p} \beta_{p} \\
& =I+\left(J^{T} J\right)^{-1} I_{m p} \frac{s+2 \zeta \omega_{n}}{b_{n}\left(s^{2}+s \zeta \omega_{n} s+\omega_{n}^{2}\right)}\left(1-Q_{k} G_{p}\right)
\end{aligned}
$$

低インピーダンスに設定するほど，実現精度の向上が期待でき る反面, 安定性の低下が予想され, 先の力ベース型とは相反す る特性を有する。

\section{4 .3 簡易位置ベース型の場合}

同様に, Fig. 5 に示す制御系における設定インピーダンスの 実現精度を求める. 各リンクの入出力特性は

$$
\begin{aligned}
& s L=s L_{r}-\beta_{h} F_{\ell} \\
& \beta_{h}=b_{n}^{-1}\left(1-Q_{k} G_{p}\right)
\end{aligned}
$$

と表される.一方, Fig. 5 より $s L_{r}$ は

$$
s L_{r}=\frac{J}{M s+B}\left\{\left(H_{r} \frac{M s^{2}+B s+K}{K}-H\right) K-F_{p}\right\}
$$

よって, 式 $(28)$ へ代入して $s L_{r}$ を消去すると，次式を得る.

$$
H_{r}-H-I_{m p}^{-1}\left\{I+\left(J^{T} J\right)^{-1} \beta_{h}(M s+B)\right\} F_{p}=0
$$

設定インピーダンスの実現精度の指標 $I D_{h}$ を

$$
\begin{aligned}
I D_{h}^{-1} & =I+\left(J^{T} J\right)^{-1} \beta_{h}(M s+B) \\
& =I+\left(J^{T} J\right)^{-1} b_{n}^{-1}(M s+B)\left(1-Q_{k} G_{p}\right)
\end{aligned}
$$

で与える. Fig. 4 (b) に示す制御系との制御性能を以下で比較・ 検討する。

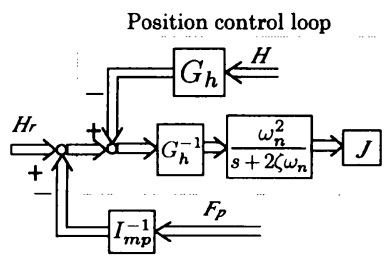

(a) Fig.4(b)

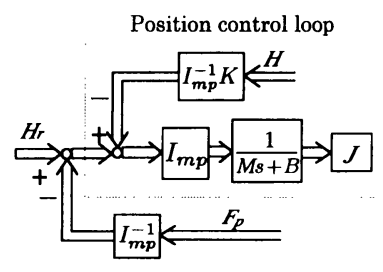

(b)Fig. 5
Fig. 6 Equivalent transformation of control systems

3.4 .4 位置ベース型と簡易位置ベース型の制御性能比較

Fig. 4 (b) と Fig. 5 における設定インピーダンスの実現精度 を比較する. 式 $(27)(31)$ はそれぞれ式 $(32)(33)$ のように変 形される。

$$
\begin{aligned}
& I D_{p}^{-1}= \\
& \quad I+\left(J^{T} J\right)^{-1} \frac{I_{m p}}{s b_{n}}\left(1-\frac{\omega_{n}^{2}}{s^{2}+2 \zeta \omega_{n} s+\omega_{n}^{2}}\right)\left(1-Q_{k} G_{p}\right) \\
& I D_{h}^{-1}= \\
& \quad I+\left(J^{T} J\right)^{-1} \frac{I_{m p}}{s b_{n}}\left(1-\frac{K}{M s^{2}+B s+K}\right)\left(1-Q_{k} G_{p}\right)
\end{aligned}
$$

両式を比較して，それぞれの制御系における設定インピーダン スの実現精度は, $G_{h}$ と $K I_{m p}^{-1}$ の周波数特性により比較される ことが分かる。

Fig. 6 は Fig. 4 (b) と Fig. 5 を等価变換したものである. 両制 御系とも $J$ 以降は同じであるため省略している. 今, Fig. 4(b) において, 点線で囲んだ位置制御部の開ループ伝達関数に対す る Fig. 5 のそれの比を $R$ とおく.

$$
R=\frac{K}{M s+B} \frac{s+2 \zeta \omega_{n}}{\omega_{n}^{2}}
$$

安定性に大きく影響を及ほす高周波域で $|R|$ は $\frac{1}{\omega_{n}^{2}} \frac{K}{M}$ に収束 する.よって, 式 $(32)(33)(34)$ より, 両制御系において, 設 
定インピーダンスの実現精度と系の安定性の比は, Fig. 4 (b) の 位置制御部に設定したモデル $G_{h}$ の固有周波数 $\omega_{n}$ と設定イン ピーダンスモデル $I_{m p}$ の固有周波数 $\sqrt{K / M}$ の大小により左 右される.

今，実現すべきインピーダンスパラメータが $\sqrt{K / M}<\omega_{n}$ の関係にあるとしよう. 式 $(32)(33)$ より, 設定インピーダン スの実現精度はFig. 4(b) の方がよいが, 高周波数域で $|R|<1$ となるため, Fig. 5 の方が高周波数域におけるループゲインが 小さく, Fig. 4 で実現できなかったインピーダンスパラメータ でも安定に実現できる可能性がある.

\section{4. 実験結果および考察}

\section{1 カベース型インピーダンス制御系}

Fig. 3 に示す制御系において，まず，設定インピーダンス の実現精度を示す指標 $I D_{f}$ のゲイン線図を Fig. 7 に示す. Fig. $7(\mathrm{a})$ (b) はそれぞれ， $K$ および $M$ を種々に変化させた 場合である。ヤコビアンはマニピュレータが基準姿勢となると きの值を用いた。 また，各制御パラメータを Table 2 に示す. (b) の $M=650[\mathrm{~kg}]$ の場合が最も高周波数域まで実現精度が よいことが予想されるが, その他の場合は共振的またはバンド 幅が狭く，実現精度および位置制御性能の両観点から満足のい く性能を得ることは容易でないことが伺える.

Fig. 8 は，目標位置 $H_{r}$ を原点に設定し， $Z$ 軸方向に種々 の周波数で加振したときの，外力と位置偏差の比を FFT 解析 したものである.Fig.8(a) (b) (c) はそれぞれ $M, B ， K$ を 種々に変化させた場合である。なお，実験は，Fig. 3 に示す制 御系において，伝達関数 $I_{m p}$ のプロパ性を保証するために，二 次のフィル夕 $E=1 /\left(1+T_{t} s\right)^{2}$ を $I_{m p}$ にかけて行った。 ま た，その時定数は系の安定性を考慮して $I_{m p} E$ の高周波ゲイン が一定 $\left(M / T_{t}^{2}=\right.$ 一定）となるように選んでいる．図中，実線は $\left|I_{m p} E\right|$ を，点線は実現性の指標まで考慮に入れた $\left|I_{m p} E I D_{f}\right|$ を示している. Fig. 7 から予想されたように，得られた結果は 設定したインピーダンスモデルとは大きくかけ離れているもの

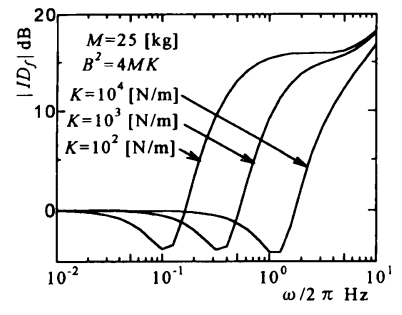

(a) Influence of $K$

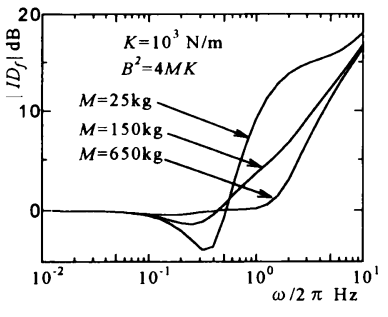

(b) Influence of $M$
Fig. 7 Frequency characteristic of indicator

Table 2 control parameters

\begin{tabular}{|c|c||c|c|}
\hline$A_{1}$ & $6.9 \times 10^{-4}\left[\mathrm{~m}^{2}\right]$ & $T_{p n}$ & $0.045[\mathrm{~s}]$ \\
\hline$m_{n}, m$ & $0.62[\mathrm{~kg}]$ & $T_{p q}$ & $0.025[\mathrm{~s}]$ \\
\hline$b_{n}, b$ & $575[\mathrm{Ns} / \mathrm{m}]$ & $\omega_{n}$ & $8.0[\mathrm{rad} / \mathrm{s}]$ \\
\hline$T_{q}$ & $0.01[\mathrm{~s}]$ & $\zeta$ & 1.0 \\
\hline$K_{p n}$ & $180[\mathrm{~Pa}]$ & & \\
\hline
\end{tabular}

の，点線とはよく一致しており，解析の妥当性が確認できる.

\section{2 位置ベース型インピーダンス制御系}

Fig. 4 に示す制御系において，まず，式 (27) に示す指標の ゲイン線図を Fig.9 に示す. (a) において, $K=10^{5}[\mathrm{~N} / \mathrm{m}]$ と 比較的大きな值に設定した場合，実現精度の大きな低下が予想 される。なお, 本研究では, 式 $(8)$ において, $P_{k n}$ のダイナ ミクスを無視している.

空気圧駆動系は空気の圧縮性のため体積弾性係数が小さく, 制御信号から圧力までの伝達部の時定数 $T_{p}$ が無視できない. そのためノミナルモデルの時定数 $T_{p n}$ も小さく設定できず, 圧

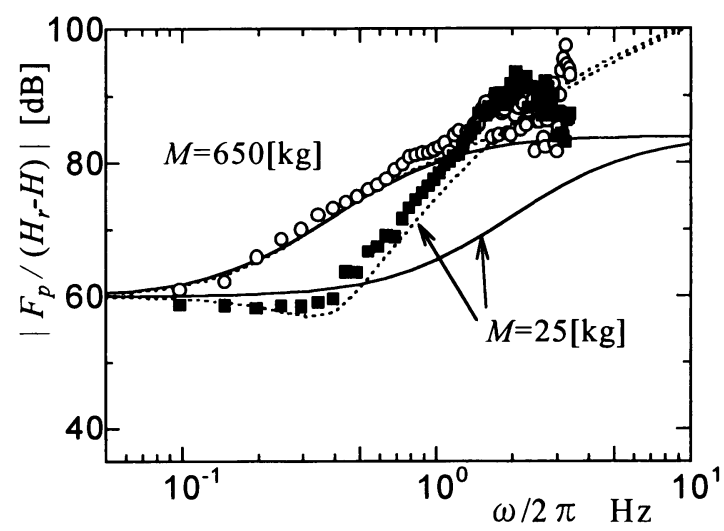

(a) Effect of changing $M$

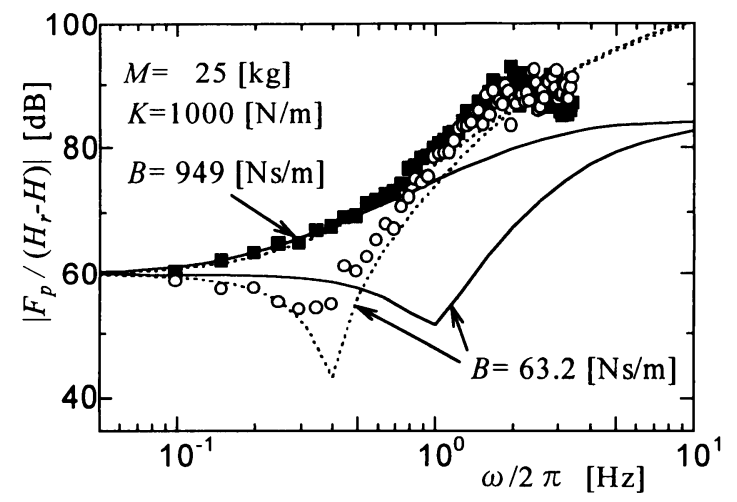

(b) Effect of changing $B$

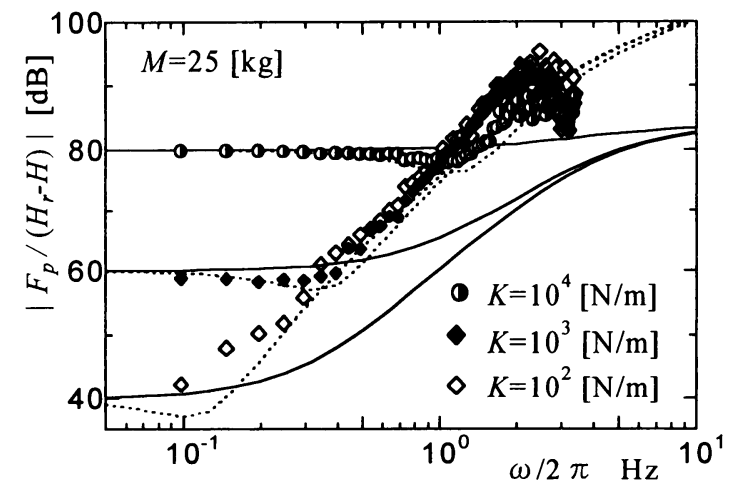

(c) Effect of changing $K$

Fig. 8 Impedance control performances of force based type ( $z$ direction) 


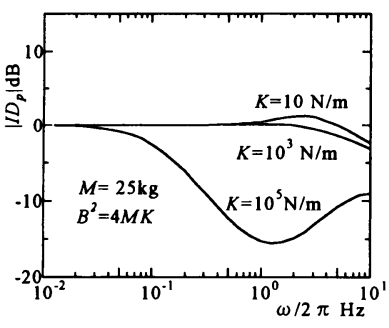

(a) Influence of $K$

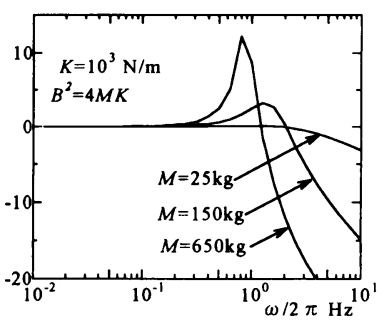

(b) Influence of $M$
Fig. 9 Frequency characteristic of indicator

力制御系 $G_{p}$ のバンド幅は狭い。この結果, $1-Q_{k} G_{p}$ のゲイ ンは低・中周波数域で十分低減されないため, 油圧や電動モー 夕等の「剛い」アクチュエータに比べて, 高インピーダンス設 定時に実現精度の低下が顕著に現れる。アクチュエータ自体柔 らかいため，見かけ上剛くするには限界がある.

実際のインピーダンス特性を Fig. 10 に示す．図中。印は Fig. 4 (a)を、・印はFig. 4(b) の制御系を用いた結果である. 両制御系とも制御性能に差は見られず, Fig. $10(\mathrm{a})(\mathrm{b})(\mathrm{c})$ と もに設定したインピーダンスをほほ満足していることが確認 できる。また，Fig.10（c)における点線はFig. 9 (a)において $K=10^{5}[\mathrm{~N} / \mathrm{m}]$ における指標 $I D_{p}$ を考慮した $\left|I_{m p} I D_{p}\right|$ を表 している．解析より予想される結果とよく一致している。 な お，Kをより小さく設定していくと Fig. 4 から分かるように カフィードバックゲインが高くなり，安定性が低下する．本制 御系では $K=10[\mathrm{~N} / \mathrm{m}]$ に設定した場合, 安定に制御動作を遂 行することはできなかった。

\section{3 簡易位置ベース型インピーダンス制御系}

Fig. 5 に示す制御系において，まず，式（31）に示す指標の ゲイン線図を Fig. 11 に示す. Fig. 11 (a) の点線は Fig. 9 に おいて $K=10^{5}[\mathrm{~N} / \mathrm{m}]$ とした場合を示している。この場合， $\sqrt{K / M}>\omega_{n}$ であるため, 設定インピーダンスの実現精度は Fig. 4 よりも優れると予想されるが, 高周波数域で式 (34)に 示した $|R|>1$ となるため, Fig. 4 に比べて安定度は低下して いる.

実際のインピーダンス特性を Fig. 12 に示す. Fig. 12 (a) (b) とも Fig. 10 に示寸結果と大差なく, 簡易型制御系でも十分 設定したインピーダンス特性を実現できることが分かる。し かし，Fig.12(c) において $K=10^{5}[\mathrm{~N} / \mathrm{m}]$ に設定した場合， 安定性を維持できなかった。また， $K=10^{4}[\mathrm{~N} / \mathrm{m}]$ に設定し た場合, $4[\mathrm{~Hz}]$ 付近で大きな共振が生じている。これは, イ ンピーダンスモデルの固有周波数を $\omega_{n}$ よりも大きく設定 （ $\sqrt{K / M}=20[\mathrm{rad} / \mathrm{s}] ） し た$ 場合には, 式（8）において無視し ていた $P_{k n}$ のダイナミクスの影響が無視できなくなり, Fig. 5 において, $H_{r}$ に作用した伝達関数 $\left(M s^{2}+B s+K\right) / K$ の出力 から $H$ までの伝達関数がもはや $K /\left(M s^{2}+B s+K\right)$ で近似で きなくなることに起因している.このように, $\sqrt{K / M}>\omega_{n}$ の 関係にあるインピーダンスパラメータを実現するには Fig. 4 の 方が優れた制御性能を示す。しかし，Fig.4では不安定となり実 現できなかった $K=10 \mathrm{~N} / \mathrm{m}$ を安定に実現できるという特筆す べき特性を有する。これは, $K=10[\mathrm{~N} / \mathrm{m}]$ では $\sqrt{K / M}<\omega_{n}$

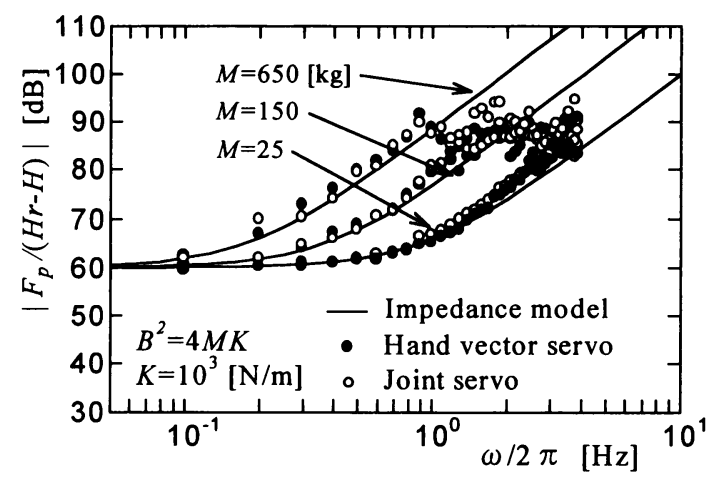

(a) Effect of changing $M$

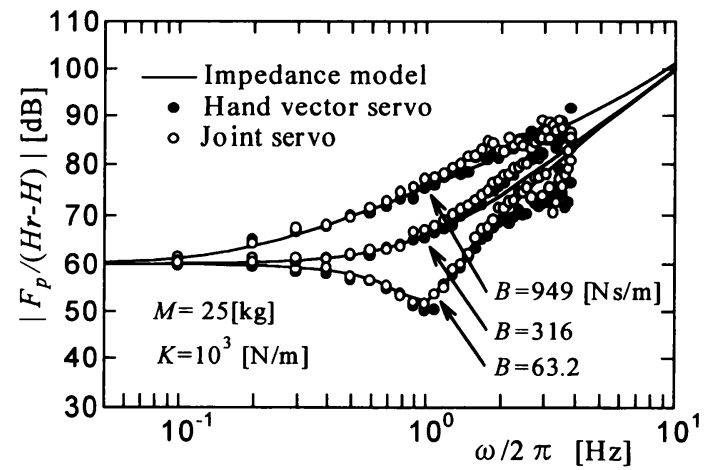

(b) Effect of changing $B$

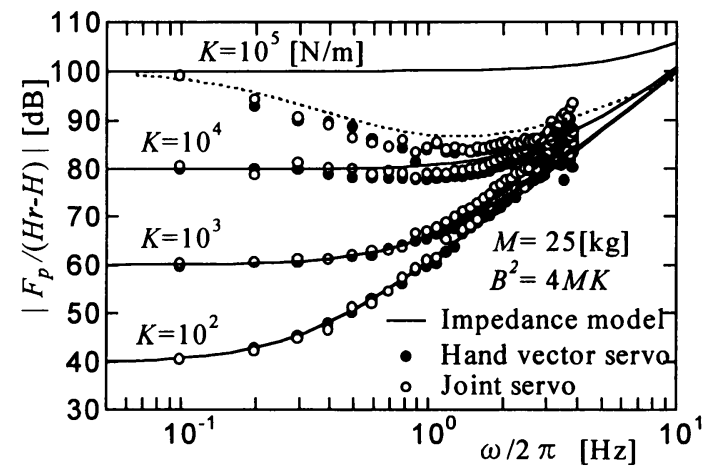

(c) Effect of changing $K$

Fig. 10 Impedance control performances of position based type ( $z$ direction)

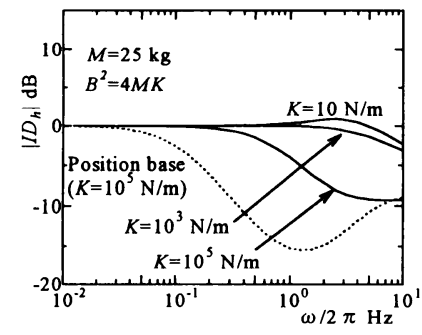

(a) Influence of $K$

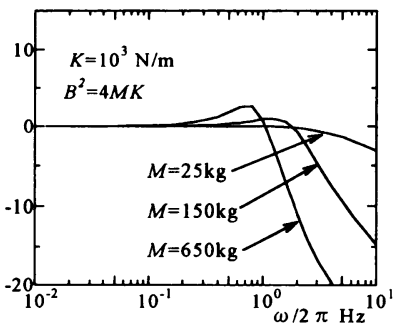

(b) Influence of $M$

Fig. 11 Frequency characteristic of indicator

となり, Fig. 5 の方が Fig. 4 より安定度が高いためであること は言うまでもない. 


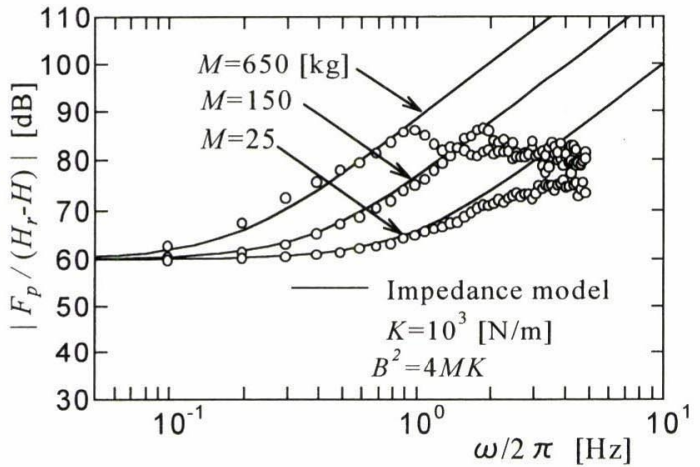

(a) Effect of changing $M$

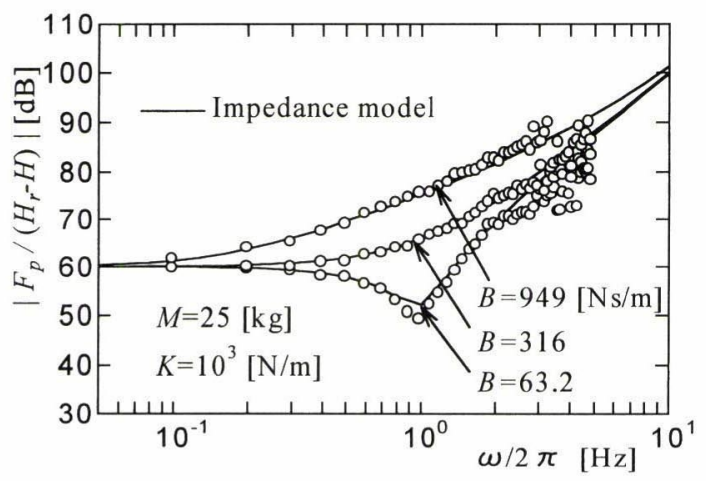

(b) Effect of changing $B$

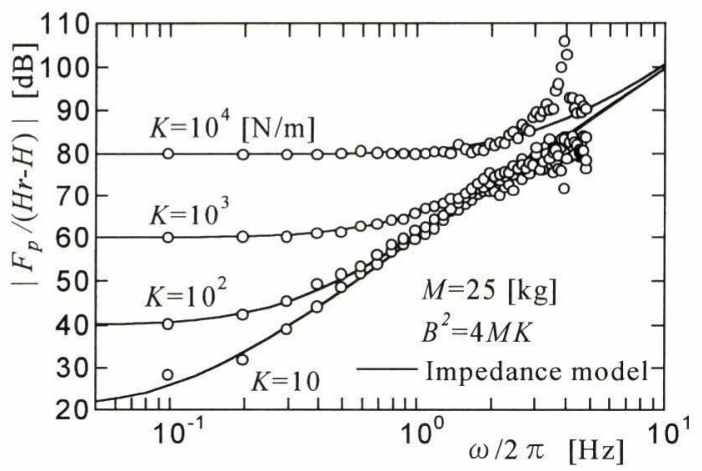

(c) Effect of changing $K$

Fig. 12 Impedance control performances of simplyfied position based type ( $z$ direction)

\section{5. 結訔}

空気式パラレルマニピュレータのインピーダンス制御を行っ
た結果，以下の結論を得た。

(1) 本研究で従来より提案している圧力制御に基づく手法を用 いて，力ベース型と位置ベース型の制御系を構成した。こ れは制御性能を悪化させる外乱を圧力の次元で推定し, こ れを相殺する圧力を生成することで制御性能を向上させよ うとするものである。また，構成した位置ベース型制御系 以外に, 新たに, 制御アルゴリズムを簡略化できる簡易位 置ベース型制御系を提案した。

(2) 構成した種々の制御系において, 設定インピーダンスの実 現精度を理論的に考察した。本マニピュレータの場合, 力 ベース型では実現精度を示す指標を高周波域まで 1 に維持 できず，実現精度および位置制御性能の観点から望ましい 応答を得ることが容易でない。一方, 位置ベース型では, 設定した任意のインピーダンス特性をほぼ実現できる。高 インピーダンスに設定するに従い精度が低下してくるが， これは空気圧固有の特性である压力応答遅れによるとこ ろが大きい. 全体的に実験により得られた結果は理論的に 予想されるものと定量的にも一致し, 解析の妥当性が示さ れた。

（3）位置ベース型と簡易位置ベース型の制御性能は，位置ベー ス型における位置の閉ループモデルの固有周波数 $\omega_{n}$ と設 定インピーダンスモデルのそれである $\sqrt{K / M}$ の大小関 係により比較できる。 $\omega_{n}<\sqrt{K / M}$ では位置ベース型の 方が制御性能に優れるが, $\omega_{n}>\sqrt{K / M}$ の状態では位置 ベース型で実現できないパラメータでも簡易位置ベース型 では安定に実現できる可能性があることを示した。

\section{参 考 文 献}

[1] N. Hogan: "Stable Execution of Contact Tasks Using Electronic Compliancy; Imedance Control," Proc. IEEE ICRA, pp.1047-1054, 1987

[2] K. Maeda, K. Fujimoto et. al.: "An Analysis of Passive Impedance of 6-D.O.F. Direct-Drive Wrist Joint," Proc. IMACS/SICE Int. symp. on RMMS'92 Kobe, pp.433-438, 1992.

[3] 大西：“電動機およびロボットの制御”, 電気学会誌, vol.110, no.8, pp.657-660, 1990.

[4] T. Noritsugu and M. Takaiwa: "Robust Positioning Control of Pneumatic Servo System with Pressure Control Loop," Proc. IEEE ICRA, pp.2613-2618, 1995.

[5] 新井：“静力学特性に基づくパラレルリンクマニピュレータの解析と 統合”, 日本ロボット学会誌, vol.10, no.4. pp.526-533, 1992.

[6] 則次, 高岩: “外乱オブザーバを用いた空気式パラレルマニピュレータの 位置決め制御”, 日本ロボット学会誌, vol.15, no.7, pp.1089-1096, 1997.

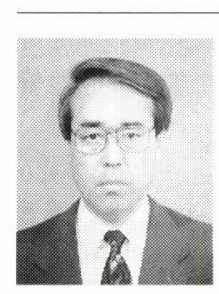

則次俊郎 (Toshiro Noritsugu)

1949 年 10 月 19 日生. 1974 年, 岡山大学大学院 工学研究科修士課程生産機械工学専攻修了. 津山 工業高等専門学校を経て, 1986 年岡山大学工学部 生産機械工学科 (現機械工学科) 助教授, 1991 年 同教授，1996 年システム工学科教授，現在に至る. 工学博士. 空気圧サーボ技術を中心としたロボティ クス, 振動制御, 制御理論の機械システムへの応用に関する研究に従 事.
(日本ロボット学会正会員)

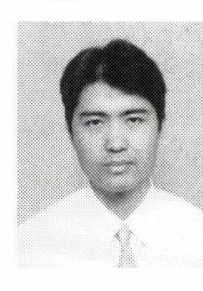

高岩昌弘 (Masahiro Takaiwa)

1967 年 7 月 17 日生. 1992 年, 岡山大学大学院工 学研究科修士課程生産機械工学専攻修了. 同年岡 山大学工学部機械工学科助手. 1996 年同システム 工学科助手. 工学博士. 空気圧サーボ系を中心と したロバスト制御の研究に従事.日本機械学会, 油 空圧学会, 計測自動制御学会などの会員.

(日本ロボット学会正会員) 